DOI: https://doi.org/10.32839/2304-5809/2021-4-92-45

УДК $811.512-161$

Телешун К.О., Свірепова А.О.

Київський національний університет імені Тараса Шевченка

\title{
ЕКВІВАЛЕНТНИЙ ПЕРЕКЛАД ТУРЕЦЬКОЇ НАУКОВО-ПОПУЛЯРНОЇ ЛІТЕРАТУРИ
}

Анотація. Стаття присвячена актуальним проблемам перекладознавства, а саме способам еквівалентного перекладу турецької науково-популярної літератури. У статті визначається зміст поняття еквівалентного перекладу та способи його досягнення за допомогою перекладацьких трансформацій як особливого виду міжмовного перефразування та невід'емної частини процесу перекладу. Розглядаються лексичні та стилістичні особливості науково-популярного підстилю. Характеризуються рівні еквівалентності перекладу: на рівні мети комунікації, опису ситуації, висловлювання, повідомлення, мовних знаків. Наведено класифікацію перекладацьких трансформацій з урахуванням відомих у літературі класифікацій різних лінгвістів які вивчали це питання. Встановлено види трансформащій, які найчастіше використовуються для досягнення еквівалентного перекладу науково-популярних турецьких текстів українською мовою. Проведено аналіз стилістичних особливостей турецького науково-популярного тексту.

Ключові слова: науково-популярна література, еквівалентний переклад, перекладацькі трансформації, мова оригіналу, мова перекладу, турецька мова.

Teleshun Kateryna, Svirepova Arina Taras Shevchenko National University of Kyiv

\section{EQUIVALENT TRANSLATION OF TURKISH SCIENTIFIC AND POPULAR LITERATURE}

Summary. The article is devoted to current problems of translation studies, namely the methods of equivalent translation of Turkish popular science literature. The article defines the meaning of the concept of equivalent translation and ways to achieve it through translation transformations as a special type of interlingual paraphrasing and an integral part of the translation process. Lexical and stylistic features of popular science background are considered. The levels of equivalence of translation are characterized: at the level of the purpose of communication, description of the situation, utterances, messages, language signs. The classification of translation transformations is given taking into account the classifications of different linguists who studied this question known in the literature. The types of transformations that are most often used to achieve equivalent translation of popular science Turkish texts into Ukrainian are identified. The analysis of stylistic features of the Turkish popular science text is carried out. The study was based on the popular science book by British evolutionist Richard Dawkins "The Blind Watchmaker» (Kör Saatçi), translated by Feryal Halyatchi, Sinan Janan and Pelin Chift's book "Secrets of the brain» (Beynin sirlarl). The main attention is paid to the study of the peculiarities of the equivalent translation of Turkish popular science texts according to certain types of grammatical transformations. According to the results of the study, grammatical transformations serve as an important means of achieving equivalence and transmission of lexical features of the Turkish popular science text. During the analysis, we found that the transfer of stylistic features of the Turkish popular science text is carried out using such means of figurative expression as comparison, metaphor and epithet. 5 meaningful levels of translation equivalence are considered and characterized, which give us to understand that the units of the original and the translation can be equivalent to each other on all five levels or only on some.

Keywords: popular science literature, equivalent translation, translation transformations, source language, target language, Turkish language.

Постановка проблеми. Проблеми перекладу тісно переплітаються з найактуальнішими проблемами сучасної теорії мови. Найбільш складною сферою перекладу залишається на сьогодні науково-популярний функщіональний стиль, основою якого е науково-популярна література. Дотепер у лінгвістиці, ще недостатньо визначені найефективніші способи перекладу турецьких науково-популярних текстів, а відомі підходи до вивчення цього питання в перекладознавчій літературі часом досить суперечливі.

Аналіз останніх досліджень і публікацій. Теоретичну основу дослідження складають теорії та положення, розроблені сучасними вітчизняними та закордонними мовознавцями. Питанню еквівалентності присвячено праці таких відомих українських учених, як Н.М. Гордієнко, А.М. Бочарнікова, також це питання вивчали такі зарубіжні вчені, як В.В. Виноградов, В.Н. Комісаров, Л.К. Латишев, Ю.А. Найда, М. Бейкер, С. Гелверсон, Дж. Кетворд, серед турецьких науковців Тахсін Акташ, Ісмаїл Бозташ й інші.
Виділення невирішених раніше частин загальної проблеми. На сучасному етапі розвитку перекладознавчої науки існуе необхідність систематизувати й обгрунтувати проблеми перекладу турецьких науково-популярних текстів адже явище еквівалентного перекладу залишається у фокусі уваги теорії перекладу та є одним із найбільш дискусійних та суперечливих. Саме тому, тема нашого дослідження $є$ актуальною.

Формулювання цілей статті. Метою дослідження $е$ визначення способів досягнення еквівалентного перекладу турецьких науковопопулярних текстів українською мовою шляхом встановлення перекладацьких трансформацій, які застосовуються для їх перекладу. Поставлена мета передбачае необхідність вирішення таких завдань дослідження:

1. З'ясувати визначення поняття перекладацька еквівалентність та п'ять типів еквівалентності.

2. Визначити поняття перекладацьких трансформацій та вивчити види трансформацій при перекладі турецьких науково-популярних текстів. 
3. Розглянути лексичні та стилістичні особливості науково-популярного підстилю.

4. Зіставити та проаналізувати турецькі науково-популярні тексти з їхніми перекладами на українську мову.

Матеріалом дослідження послугувала науково-популярна книга британського еволюціоніста Річарда Докінза «Kör Saatçi» («Сліпий годинникар») перекладена Фер'яль Халятчи та книга Сінана Джанана й Пелін Чіфрт «Веynin surları» («Таємниці мозку»).

Виклад основного матеріалу. На сьогоднішній день у перекладознавстві до кінця не вирішено питання щодо методів досягнення еквівалентного перекладу науково-популярних текстів. Цей специфічний жанр є дуже важливим адже він $є$ «містком» між спеціальною літературою, що містить великий обсяг наукової інформації та неспеціальною. Науково-популярний текст має в доступній і цікавій формі донести до адресата наявний матеріал. Він не переслідуе мети дати послідовне викладення наукових концепщій. Тексти даного стилю знайомлять читачанеспещіаліста 3 науковими даними за допомогою певної обробки нових знань [1, с. 147].

Термін «еквівалентність» відображає смислову близькість вихідного тексту з його перекладом i був введений з огляду на те, що досягти повної схожості між ними майже неможливо. Американський дослідник Ю. Найда стверджує, що переклад полягає в створенні «найближчого природного еквівалента» оригіналу мовою перекладу [6, с. 26-27]. В. Н. Комісаров пропонуе наступне визначення цього поняття: еквівалентність - це «максимально можлива лінгвістична близькість тексту перекладу до тексту оригіналу» [3, с. 87].

У своїй статті під назвою «Переклад та еквівалентність у перекладі» Ісмаїл Бозташ описує еквівалентність наступним чином: «Це - багатогранне поняття, засноване на різних елементах». За словами Бозташа: «Переклад - це не лише здатність встановити граматичну еквівалентність між мовою оригіналу та мовою перекладу. Переклад - це також здатність передавати висловлювання мовою оригіналу найбільш природним чином 3 точки зору значення, фрункції та культури» [5].

В.Н. Комісаров виокремлюе п'ять типів еквівалентності, на які ми і будемо спиратися у нашому дослідженні.

1. Рівень мети комунікації, що полягає у вираженні емоцій мовця. Мовні засоби перекладу на цьму рівні не відповідають мовним засобам оригіналу [3 с. 56]. Наприклад:

Bana bir iyilik yapar misinız? - Будыте ласкавi, зробити мені послугу.

Sorun seni üzmeden sorunu dert etme - He чinaŭ лихо, доки воно тихе.

Ne var ne yok? - Як справи?

2. Рівень опису ситуації. Загальна частина змісту тексту оригіналу і перекладу крім передачі однієї мети комунікації відображає схожу мовну ситуацію. Наприклад:

Kusura bakmayın, kasten yapmadım - Вибачте, я ненавлисно.

Islak bоуа - Обережно, поббарбовано.

It-çek - Від себе/до себе.

Elinize sağlı - Дуже дякуєл, було слачно.
3. Рівень висловлювання, на якому зберігаються компоненти змісту, а також значна частина синтаксичних конструкцій висхідної мови, при цьому еквівалентність на рівні слів відсутня. Наприклад:

Annesine çekmiş - Вiн схожий на малу. (Весь в suasy).

Hastalı̆̆ından sonra kemik torbast gibi olduПілся хвороби вона вихудла як тріска.

Havamda değilim - Мені не до жартів.

İş işten geçti - Вже запізно.

4. Рівень повідомлення. На даному рівні інформація, що міститься в структурі тексту оригіналу, входить в загальний зміст тексту перекладу. Наприклад:

Limana sadece gelgitte büyük gemiler girebilir Великі кораблі можуть заходити в порт лише під час припливу.

5. Рівень мовних знаків. На даному рівні досягається максимально можлива еквівалентність змісту між тестом оригіналу та текстом перекладу. Наприклад:

Her anne çocuklarını sever - Кожна мимла любить своїx dimeŭ.

Sana her hafta yazacă̆ım - Я будy nucamu тобі шотижня.

Для того аби досягнути еквівалентного перекладу та передати точний зміст того, що хотів донести до нас автор, використовуються перекладацькі трансформації. ЯІ. Рецкер називає перекладацькими трансформаціями «прийоми логічного мислення, за допомогою яких ми розкриваємо значення іншомовного слова в контексті і знаходимо йому відповідник, який не збігаеться із словниковим» [4].

В.Н. Комісаров поділяе перекладацькі трансформації на лексичні і граматичні. До лексичних трансформацій відносять: транскрибування і транслітерацію, калькування. До граматичних трансформацій належать: синтаксичне уподібнення (дослівний переклад), об'єднання речень, граматичні заміни (форми слова, частини мови або члена речення). В свою чергу комплексні лексико-граматичні трансформації включають: антонімічний переклад, експлікацію (описовий переклад) та компенсацію [3, с. 43].

Калькування полягає в заміні складових частин (слів, морфем) лексичної одиниці оригіналу лексичними відповідниками. Даний спосіб породжує нове слово, що копіюе структуру вихідної одиниці [3, с. 45].

Так як головною метою науково-популярних текстів $є$ ознайомлення читача 3 науковими поняттями і явищами зрозумілою неспеціалісту формі, у них використовуються особливі мовні засоби, які відсутні у власне-науковому стилі. Науково-популярні тексти характеризуеться наявністю специфрічних лінгвістичних і стилістичних засобів, котрі безпосередньо або опосередковано висловлюють позицію автора як представника певної культури стосовно проблеми, розглянутої у статті. Для них характерні використання різних художніх засобів. Одним 3 поширених засобів образної виразності в науково-популярних текстах є метафори. Провідною фрункцією метафрори в науково-популярному творі, е розкриття сутності наукового поняття, пізнавальна фрункція [2, с. 8]. 
«İnsan vücudu devasa bir hücreler topluluğudur. Bu $\mid$ «Людське тіло-без перебільшення колосальна популяція hücrelerin hepsi tek bir atadan, döllenmiş yumurtadan клітин, і всі вони походять від одного прабатька gelir ve bu yüzden de diğer vücut hücrelerinin kuzenleri, заплідненої яйцеклітини; і тому всі вони е кузенами, çocukları, torunları, amcaları, vs. olurlar.» дітьми, онуками, дядьками і т. д. один одного» «...organik bir «ilksel çorba'yı» temel alan kuramlar ..» «...теорії, засновані «первісного бульйону»

Одним з яскравих лексичних образних засобів, що зустрічаються в тексті, є епітет. Цей засіб худож- ньої виразності надає розповіді особливу емоційність та підкреслюе визначальну рису певного предмета.

\begin{tabular}{|c|c|}
\hline «İşte size büyüleyici bir düşünce» & «Ось вам і захоплююча думка» \\
\hline «Öyleyse, salt bizim çelimsiz hayal gücümüze değil..» & «Тож не лише для нашої тендітної уяви..» \\
\hline $\begin{array}{l}\text { "...bizim küçük yaşamlarımız üzerinde astrolojik } \\
\text { etkiler göstermek için yön değiştirdiklerini öğrettiği } \\
\text { zamanları anımsatmiyor mu?» }\end{array}$ & $\begin{array}{l}\text { «...хіба це не нагадуе вам про часи, коли він навчав } \\
\text { нас змінювати напрямок, щоб мати астрологічний } \\
\text { вплив на наші жалюгідні життя?» }\end{array}$ \\
\hline «...böylesine müsrif bir kuramı benimseyebiliriz» & «...ми можемо прийняти таку марнотратну теорію» \\
\hline
\end{tabular}

У тексті ми також зустрічаємо порівняння, які є еквівалентними в обох мовах.

\begin{tabular}{|c|c|}
\hline \begin{tabular}{|llll} 
«Bu yarasalar minyatür casus uçakları gibi \\
karmaşı aletlerle dolu»
\end{tabular} & $\begin{array}{l}\text { «Ці кажани сповнені складних пристроїв, на } \\
\text { мініатюрні літаки-розвідники» }\end{array}$ \\
\hline & \\
\hline $\begin{array}{l}\text { Bu açıda } \\
\text { inlerce } \mathrm{r} \\
\text { ibidir a }\end{array}$ & $\begin{array}{l}\text { «З ціеї точки зору мозок схожий на розважальний } \\
\text { центр } 3 \text { тисячами неонових вивісок, які постійно } \\
\text { блимають» }\end{array}$ \\
\hline
\end{tabular}

У більшості випадків такий прийом, як калькування, використовуеться для перекладу реалій, коли знайти еквівалент поняття не вдається через відмінність культур. Однак наведені нижче при- клади демонструють, що, головним чином, перекладач вдається до даного прийому для перекладу термінів. У даному випадку калькування дозволяе в повній мірі розкрити значення поняття.

«Işı̆̆ın ilk vurduğu şey ışığa duyarlı ışık hücreleri değildir...»

"Yine de, doğal seçilimin yaşayan canlı sonuçları..."

«Перше, на що потрапляє світло, це не світлочутливі клітини...»

«Atımlar siddetli olmalıdır, çünkü yayınlanan ses «Імпульси повинні бути інтенсивними, оскільки dalgasının cephesi sürekli genişleyen bir küre şeklinde ilerler»

«Radar sinyallerini bir dizi atım olarak düşünebiliriz, fakat her atımın bir taşıyıcı frekansı vardır»

«Ми можемо сприймати радарні сигнали як серію імпульсів, але кожен імпульс має несучу частоту»

Наступні приклади демонструють, що, незважаючи на можливість прямого перекладу, ми також можемо застосувати антонімічний переклад.

«Derin denizlerdeki balıklar ve balinalar gündüz de gece ışığı çok az görebilir ya da hiç görenemez, çünkü güneşin işıklarıderinlere sızamaz»

«...çünkü beyinlerimiz kitle iletişim araçlarının egemen olduğu bir ortamda evrilmedi»

«Ondan sonra gelenler, her şeyde evrim görmeye meylettiler»

Висновки та перспективи подальших досліджень. Отже, еквівалентний переклад $є$ особливою формою перекладу і дозволяе перекладачу максимально наблизити текст перекладу до оригіналу. Під час проведеного аналізу ми встановили, що передача стилістичних особливостей турецького науково-популярного тексту здійснюеться за допомогою таких засобів образної виразності як порівняння, метафора та епітет. Розглянуто та схарактеризовано 5 змістовних рівнів еквівалентності перекладу за В.Н. Комісаровим, які дають нам зрозуміти про те, що одинищі оригіналу та перекладу можуть бути еквівалентні одна одній на всіх п'яти рівнях або лише на деяких. В результаті
Це зроблено з стилістичних міркувань, оскільки в такому варіанті перекладний текст виглядає більш «природно» [7].

«Глибоководних риб і китів теж оточуе повна або майже повна темрява - i вдень, і вночі, тому що промені сонця не можуть проникати глибоко в воду»

«...тому що наш мозок еволюціонував в середовищі, де були відсутні засоби масової інформації»

«Його послідовники не встояли від спокуси бачити еволюцію в усьому»

аналізу було виявлено, що, поряд з великою кількістю термінів, в науково-популярних текстах активно використовуються стилістичні фрігури мови. Як правило, для них підшукуються еквіваленти, здійснюеться дослівний переклад або підбираються фоункціональні аналоги. Для досягнення еквівалентності та передачі лексичних особливостей турецького науково-популярного тексту використовуються такі лексичні і граматичні трансформації як антонімічний переклад та калькування. Передача стилістичних особливостей, виражених такими художніми засобами, як метафора, епітет i порівняння переважно здійснюеться за допомогою використання дослівного перекладу. 


\section{Список літератури:}

1. Бацевич Ф. Основи комунікативної девіатології. Львів : ЛНУ ім. Івана Франка, 2000. 236 с.

2. Кожина М.Н. О функциональных семантико-стилистических категориях в аспекте коммуникативной теории языка / Разновидности и жанры научной прозы: Лингвостилистические особенности. Москва : Наука, 1989. C. $7-12$.

3. Комиссаров В.Н. Общая теория перевода : учеб. пособие. Москва : «ЧеРо», совместно с «Юрайт», 2000.136 с.

4. Рецкер Я.И. Теория перевода и переводческая практика. Москва, 2007.

5. Boztaş İsmail (1993) «Çeviri, Dilbilim İlişkisi, Çeviride Eşdeğerlik ve Kayıplar». H.Ü. Edebiyat Fakültesi Dergisi. Cilt 10, Sayı 2, Ankara.

6. Nida E.The Theory and Practice of Translation. E.A. Nida, C.R. Taber. Leiden : E J. Brill, 1982. Pp. 1-50.

7. «Kör Saatçi». URL: https://evrimteorisionline.files.wordpress.com/2010/12/kc3b6rsaatc3ai.pdf

\section{References:}

1. Batsevych F. (2000). Osnovy komunikatyvnoyi deviatologiyi [Fundamentals of communicative deviatology]. Lviv: Ivan Franko National University of Lviv, 236 p. (in Ukrainian)

2. Kozhina M.N. (1989). O funktsional'nyh samantiko-stilestlcheskih kategoriyah v aspekte komunikativnoy teoriyi yazyka / Raznavidnosti i zhanry nauchnoy prozy: Lingvisticheskiye osobenosti [On functional semantic and stylistic categories in the aspect of the communicative theory of language / Varieties and Genres of Scientific Prose: Linguistic and Stylistic Features]. Moscow: Nauka, pp. 7-12. (in Russian)

3. Komisarov V.N. (2000). Obshaya teoriya perevoda: ucheb. posobiye [General theory of translation: textbook]. Moscow: «CheRo», jointly with «Yurayt», 136 p. (in Russian)

4. Retsker Ya.I. (2007). Teoriya perevoda i perevodcheskaya praktika [Translation theory and translation practice]. Moscow. (in Russian)

5. Boztash Ismail (1993). «Cheviri, Dilbilim Ilishkisi, Cheviride Eshdegerlik ve Kayiplar» [Translation, Linguistics Relation, Equivalence and Loss in Translation]. H.U. Journal of the Faculty of Letters, vol. 10, issue 2, Ankara.

6. Nida E. (1982). The Theory and Practice of Translation. E.A. Nida, C.R. Taber. Leiden: E J. Brill, pp. 1-50.

7. «The Blind Watchmaker». Available at: https://evrimteorisionline.files.wordpress.com/2010/12/kc3b6rsaatc3ai.pdf 